This is an Open Access article, distributed under the terms of the Creative Commons Attribution licence (http://creativecommons.org/licenses/by/4.0/), which permits unrestricted re-use, distribution, and reproduction in any medium, provided the original work is properly cited.

\title{
Beyond Plague Pits: Using Genetics to Identify Responses to Plague in Medieval Cambridgeshire
}

\author{
Craig Cessford $^{1,2}$ (D), Christiana L. Scheib ${ }^{3}$ (D), Meriam Guellil $^{3}$ (D), \\ Marcel Keller ${ }^{3}$ (i) , Craig Alexander ${ }^{4}$ (D), Sarah A. Inskip ${ }^{5}$ (i) AND \\ JoHn E. RobB ${ }^{6}$ (D) \\ ${ }^{1}$ McDonald Institute for Archaeological Research, University of Cambridge, UK \\ ${ }^{2}$ Cambridge Archaeological Unit, University of Cambridge, UK \\ ${ }^{3}$ Institute of Genomics, University of Tartu, Estonia \\ ${ }^{4}$ Independent researcher, Brescia, Italy \\ ${ }^{5}$ School of Archaeology and Ancient History, University of Leicester, UK \\ ${ }^{6}$ Department of Archaeology, University of Cambridge, UK
}

Ancient DNA from Yersinia pestis has been identified in skeletons at four urban burial grounds in Cambridge, England, and at a nearby rural cemetery. Dating to between AD 1349 and 1561, these represent individuals who died of plague during the second pandemic. Most come from normative individual burials, rather than mass graves. This pattern represents a major advance in archaeological knowledge, shifting focus away from a few exceptional discoveries of mass burials to what was normal practice in most medieval contexts. Detailed consideration of context allows the authors to identify a range of burial responses to the second pandemic within a single town and its hinterland. This permits the creation of a richer and more varied narrative than has previously been possible.

Keywords: plague, second plague pandemic, ancient DNA, burials, Cambridge

\section{Introduction: Where Are All the Plague Dead?}

The second plague pandemic (as opposed to the first plague pandemic in the sixtheighth centuries $\mathrm{AD}$ ) arrived in Europe in the middle of the fourteenth century, starting with the Black Death (AD 13461353) which killed around forty to sixty per cent of the population. Frequent recurrences of the disease followed until the mid-seventeenth century, with outbreaks continuing until the early eighteenth century. The second pandemic, and the Black Death in particular, continue to fascinate the public, historians (Benedictow, 2004; Green, 2015), and increasingly geneticists (Spyrou et al., 2019). The impact of the plague on Cambridge in England was probably devastating. In $1365 / 1366$, the bishop granted permission for the parishes of All Saints by the Castle 
and St Giles to merge, as 'the parishioners of All Saints are for the most part dead by pestilence, and those that are alive are gone to other parishes, the nave of All Saints is ruinous and the bones of dead bodies are exposed to beasts' (HMC, 1877: 299, folio 1026).

Plague kills rapidly, with a typical incubation period of two to six days for bubonic plague (Dennis et al., 1999: 43), followed by a further three to five days when fifty to ninety per cent of individuals with septicaemia from bubonic plague and no access to antibiotics die (Sexton \& Stout, 2018). This speed means that the disease leaves no visible traces on the skeleton, so plague victims cannot be identified through osteological analysis. Archaeologists seeking to identify individuals who died of plague have traditionally relied on contextual evidence, such as 'emergency' cemeteries that textual sources indicate were established specifically in response to plague outbreaks, or mass burials. In Britain, these include several sites in London: the East and West Smithfield Black Death cemeteries (Grainger et al., 2008; Pfizenmaier, 2016) and later burials at the Cistercian Abbey of St Mary Graces (Grainger \& Phillpotts, 2011) and New Churchyard (Hartle, 2017) (Figure 1). Outside London, there are fourteenthcentury mass burials at Hereford Cathedral (Stone \& Appleton-Fox, 1996) and Thornton Abbey (Willmott et al., 2020), and mid-seventeenth-century plague burials at Leith in Scotland (Stoakley, 2019).

While historians and archaeologists acknowledge that most people killed by plague were buried individually in ordinary cemeteries, these skeletons have previously been almost impossible to recognize and attention has thus focused on the exceptional mass burials. In rare cases, as at the Hull Augustinian Friary where coffins were closely dated by dendrochronology, it has been possible to suggest that some individual burials relate to the Black
Death (Evans, 2002: 28-29). For understandable reasons, genetic investigations of medieval plague have also focused on the exceptional mass burials. Inadvertently and unintentionally, the exceptional came to appear typical. To put it in stark figures: between one and four million people died in England in the Black Death outbreak alone, to say nothing of subsequent outbreaks, but probably no more than a few tens of thousands were buried in mass graves. Where are all the others and would finding them change the direction of research on historic epidemics? The aim of this article is to consider some individuals from Cambridgeshire that, through a mass screening of ancient DNA (aDNA), can be shown to have died of plague during the second pandemic and the types of burial that they received.

\section{Researching the Plague in Medieval Cambridgeshire}

In researching the second pandemic, the key breakthrough has been biomolecular as the aDNA of Yersinia pestis, the bacterium that causes plague, has been recovered from human teeth. This is possible because, when individuals develop septicaemia, where bacteria enter the blood and spread throughout the body, these will enter the blood vessels present in tooth pulp. Given the high level of mortality once a plague victim develops septicaemia and the physiological improbability of maintaining a bacterial load in the blood upon survival, finding $Y$. pestis in a human tooth root almost certainly indicates that the person died of plague. Thus, it is now possible to identify the skeletons of plague victims in a way that was previously impossible.

Attempts to identify $Y$. pestis associated with both the first and second pandemic initially focused on emergency cemeteries and mass burials (for recent summaries, 


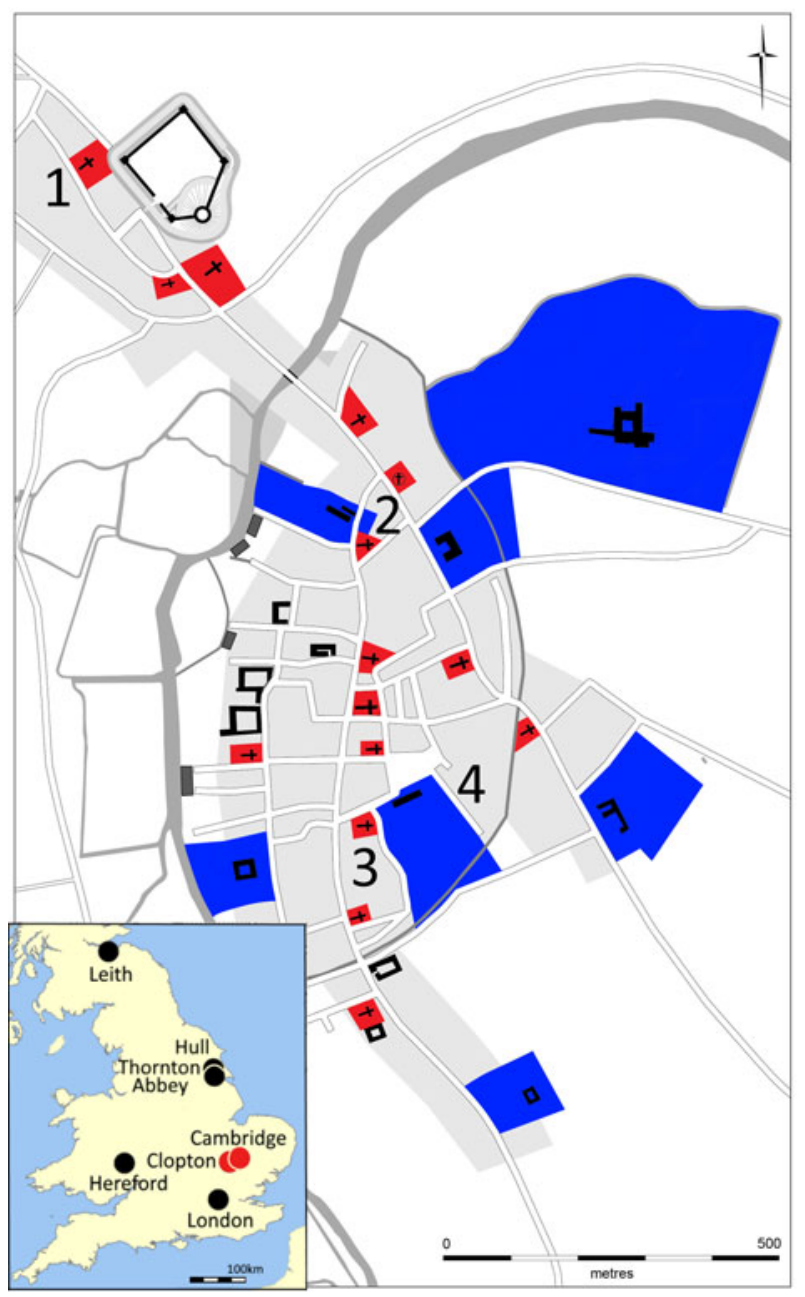

Figure 1. Map of sites mentioned in the text and plan of parish cemeteries (red) and other religious institutions (blue) in Cambridge c. 1350. 1) All Saints; 2) Hospital of St John; 3) St Bene't's; 4) Augustinian Friary (plan by Vicki Herring for the 'After the Plague' project, adapted by Craig Cessford).

see Keller et al., 2019; Spyrou et al., 2019). Work on prehistoric remains has been rather different: skeletal material was initially sampled for human aDNA and only later screened for pathogen aDNA, with $Y$. pestis identified from burials that were not particularly distinctive or unusual (Rasmussen et al., 2015). Concentrating initially on skeletons that are identifiable from their archaeological context as probable plague victims is a logical first step. It allows the method to be tested on subjects with expected positive results and enables research goals such as outlining the phylogenetic history of the pathogen. However, it offers only limited contributions to the social archaeology of medieval epidemics per se. For that, a different approach is needed: screening a variety of contexts, and particularly apparently ordinary-looking burials, for plague victims.

By the mid-fourteenth century, Cambridge was a well-established town, containing a significant number of religious 
and educational institutions. Its population immediately before the Black Death was probably around 5800 inhabitants (Casson et al., 2020: 318). Although textual records amenable to statistical analysis do not survive, the available evidence indicates that Cambridge was affected in a manner broadly similar to the rest of England. If some forty to sixty per cent of the estimated population died, that would be around 2300-3500 fatalities. In the mid-fourteenth century, burial was permitted at a significant number of locations in the town: seventeen parish churches, four friaries, a hospital, a nunnery, and two priories. There is no evidence for the establishment of fourteenth-century emergency cemeteries; those who died of plague were therefore presumably buried at their parish churches or other religious institutions as appropriate.

Plague outbreaks continued intermittently until 1665/1666. The frequency and severity of these repeated outbreaks is impossible to assess accurately; it is however likely that most decades saw at least one outbreak. These later outbreaks were less severe than the initial Black Death. Some late fourteenth- to early sixteenth-century outbreaks may have killed some ten to twenty per cent of the population, while later outbreaks with more reliable figures killed up to five per cent (in 1574, 1630) and twelve per cent (in 1665/1666) of the population of Cambridge. Burial of plague victims continued to take place in parish churches and other religious institutions, although the latter's number changed over time, particularly with the acquisition of burial rights by some colleges from the 1440s onwards and the Dissolution in 1538.

From 1574 onwards, some individuals infected with the plague were isolated and moved to 'pest houses', groups of timber structures within ditched enclosures located some distance from the town in its surrounding fields. Although primarily intended to isolate the living, pest houses included, from at least 1603 onwards, the burials of some individuals who had died there. The location of the pest houses changed over time, with at least four sites known: Balls's Folly (1574), Midsummer Common (1593-1630), Jesus Green (1603-1647) and Coldham's Common (1647-1666, retained until 1703). Most burials continued to take place in parish cemeteries, with perhaps twenty per cent of burials in pest houses.

\section{Methods}

'After the Plague' (http://www.aftertheplague. com) is a multidisciplinary research project studying human remains from Cambridge, with a principal focus on the later medieval period (1100-1500) but including material ranging from the Early Neolithic to the Late Modern periods. This includes palaeogenetic analysis of teeth to study human and pathogen aDNA, including data from five burial grounds that at least partly overlap with the second pandemic. The burial grounds were selected to cover as wide a range of burial contexts as possible, the main limiting factor being the availability of human skeletal remains. The burial grounds include an urban parish cemetery, the cemetery and chapter house of an urban friary, an urban hospital cemetery, and a rural parish cemetery. None of these burial grounds was established in response to plague outbreaks and the skeletons sampled were overwhelmingly from individual burials that follow the typical rites of the period. Given their dates, it was probable that some of the individuals in these cemeteries died of plague, but there was nothing to identify any particular burials as plague-related. In total, 191 skeletons from the five burial grounds were sampled and tested for human and pathogen aDNA. In addition, four 
skeletons from a mass burial in another urban parish cemetery and two associated with a pest house were also sampled. Numbers of individuals in each cemetery likely to have died during the second pandemic were assessed utilizing textual sources, stratigraphy, radiocarbon dating, and artefact typology.

This article focuses on presenting the archaeological context of this research; technical details of genetic results will be published elsewhere. Next Generation Sequencing (NGS) data from ancient human tooth roots were screened bioinformatically for $Y$. pestis using one of two different methods: the MEGAN alignment tool (MALT), post-processed within the pathogen screening pipeline HOPS19 (Hübler et al., 2019), and a kmer-based approach using KRAKEN 2 (Wood et al., 2019). The assessment of these shotgunapproach NGS reads produced from libraries without uracil-DNA-glycosylase treatment revealed the potential presence of $Y$. pestis aDNA. These were genotyped, based on the inspection of their single nucleotide polymorphisms profiles. Information on the various sites and skeletons discussed and on the radiocarbon dating methodology are provided in the online supplementary material.

\section{Results}

Overall, out of a total of 197 individuals screened, ten samples tested positive for $Y$. pestis, plus a further three possible instances (likely to be positive but lacking enough data to definitely confirm the presence of the pathogen). Eight positive and two tentative identifications came from single burials in normal parish cemeteries and religious establishments, including the parish cemetery of All Saints by the Castle, both the cemetery and chapter house of the Augustinian Friary, and the rural parish of
Clopton (Figure 1, Tables 1-2). Two of the samples were subjected to further analysis and have been previously published (Spyrou et al., 2019). Another Cambridge cemetery at the Hospital of St John appears to be free of plague burials.

Of the four skeletons tested from a mid-fourteenth mass burial at St Bene't's parish cemetery, two gave positive results and one gave a tentative identification. Two burials probably associated with sixteenth- to seventeenth-century pest houses on Midsummer Common tested negative for $Y$. pestis; these potentially represent false negatives. From these it is possible to calculate the percentage of skeletons out of those likely to date to second pandemic that tested $Y$. pestis positive or tentative (Table 1). These results while interesting, must be accompanied by a strong warning, particularly with regard to differential aDNA preservation and availability, and should not be simplistically interpreted as mortality rates for the plague.

\section{All Saints by the Castle}

All Saints by the Castle in Cambridge (henceforth All Saints) was a parochial church founded in c. 940-1150 (Figure 1). It endured for between three and five centuries, before it was merged with another parish in 1365/1366. Given that date, the merging of the parishes presumably does not relate to the Black Death of 13481349 , although this undoubtedly contributed to it, but to the next plague outbreak in 1361-1362, which may have claimed the lives of ten to twenty per cent of the population.

In total, forty-nine skeletons from the cemetery were sampled for aDNA. It is estimated that twenty-two of these individuals may have died during the second pandemic. Many of these individuals could also have died before the second 
Table 1. Skeletons from burial grounds contemporary with the second pandemic in Cambridge 1349-1666 sampled for aDNA.

\begin{tabular}{|c|c|c|c|c|c|c|c|}
\hline Site & $\begin{array}{l}\text { Date of } Y . \\
\text { pestis positive } \\
\text { burials }\end{array}$ & $\begin{array}{l}\text { No. } \\
\text { sampled }\end{array}$ & $\begin{array}{c}\text { No. likely to } \\
\text { date to } \\
1349-1666\end{array}$ & $\begin{array}{l}\text { No. } \\
\text { positive }\end{array}$ & $\begin{array}{c}\text { No. } \\
\text { tentative }\end{array}$ & $\begin{array}{l}\text { No. negative } \\
\text { results from } \\
\text { burials } \\
\text { believed to be } \\
\text { plague related }\end{array}$ & $\begin{array}{c}\% \text { positive/ } \\
\text { tentative of } \\
\text { those likely to } \\
\text { date to second } \\
\text { pandemic }\end{array}$ \\
\hline $\begin{array}{l}\text { All Saints, } \\
\text { parish } \\
\text { cemetery }\end{array}$ & 1349-1361/62 & 49 & $5-11$ & 1 & 0 & $\mathrm{n} / \mathrm{a}$ & $9-20$ \\
\hline $\begin{array}{l}\text { St Bene't's, } \\
\text { mass burial, } \\
\text { parish } \\
\text { cemetery }\end{array}$ & $1349-1352 / 77$ & 4 & 4 & 2 & 1 & 1 & 75 \\
\hline $\begin{array}{l}\text { Clopton, parish } \\
\text { cemetery }\end{array}$ & $1349-1561$ & 17 & $11-17$ & 3 & 2 & $\mathrm{n} / \mathrm{a}$ & $29-45$ \\
\hline $\begin{array}{l}\text { Augustinian } \\
\text { Friary, } \\
\text { cemetery }\end{array}$ & 1349 & 22 & $4-8$ & 1 & 0 & $\mathrm{n} / \mathrm{a}$ & $12-25$ \\
\hline $\begin{array}{l}\text { Augustinian } \\
\text { Friary, } \\
\text { chapter } \\
\text { house }\end{array}$ & 1450-1538 & 6 & 6 & 3 & 0 & $\mathrm{n} / \mathrm{a}$ & 50 \\
\hline $\begin{array}{l}\text { Hospital of St } \\
\text { John, } \\
\text { cemetery }\end{array}$ & 1349-1511 & 97 & $47-57$ & 0 & 0 & $\mathrm{n} / \mathrm{a}$ & 0 \\
\hline $\begin{array}{l}\text { Midsummer } \\
\text { Common, } \\
\text { pest house }\end{array}$ & 1550-1666 & 2 & 2 & 0 & 0 & 2 & 0 \\
\hline Total & 1349-1666 & 197 & 79-105 & 10 & 3 & 3 & $12-16$ \\
\hline
\end{tabular}

pandemic, so perhaps only some five to eleven individuals died in 1349-1365. Although there is no way to determine which specific skeletons these are, and the estimates are, admittedly, imprecise, similar calculations have been carried out for the other burial grounds. At All Saints, one skeleton (no. 82) tested positive for $Y$. pestis aDNA (Figure 2; for details on this and other skeletons see Table 2). This was an extended supine burial, with head to the west, in an earthcut grave, that was typical of the graves in the cemetery. As such, Grave 82 acts as a representative for all the individuals in Cambridge who died of plague and received a normal individual parochial burial, which may well have been most of the deceased. This individual could have died in either the 1349 or 1361-1362 outbreaks. The double burial of two probably clothed individuals (143 and 156) face down in a single grave at All Saints was the latest interment in the local stratigraphic sequence. These skeletons were not sampled for aDNA, as both skulls had been removed by later truncation, but death from plague is plausible.

All Saints was abandoned after the 1361-1362 outbreak; there is no evidence for later burials or that the site was used for other purposes during the rest of the second pandemic. This indicates that the amalgamated parish community, based only $200 \mathrm{~m}$ away at St Giles, did not retain and continue to use the burial ground, despite continued plague 
Table 2. Individuals who tested positive or tentative for Y. pestis aDNA, or where archaeological context indicates that they probably died of plague.

\begin{tabular}{|c|c|c|c|c|c|c|}
\hline Site & Skeleton & Result & Date & Sex & $\begin{array}{l}\text { Age at death } \\
\text { (years) }\end{array}$ & Comment \\
\hline All Saints & 82 & Positive & 1349 or $1361 / 62$ & M & $46-59$ & Individual burial \\
\hline All Saints & 143 & Unsampled & 1349 or $1361 / 62$ & M & $36-45$ & Double burial, face down and probably clothed \\
\hline All Saints & 156 & Unsampled & 1349 or $1361 / 62$ & M & $26-35$ & Double burial, face down and probably clothed \\
\hline St Bene't's & 1605 & Unsampled & Prob. 1349 & Unknown & $18+$ & Multiple burial \\
\hline St Bene't's & 1608 & Positive & Prob. 1349 & $\mathrm{~F}$ & $18-25$ & Multiple burial \\
\hline St Bene't's & 1609 & Positive & Prob. 1349 & M & $26-35$ & Multiple burial \\
\hline St Bene't's & 1610 & Tentative & Prob. 1349 & M & $18+$ & Multiple burial \\
\hline St Bene't's & 1612 & Negative & Prob. 1349 & M & $18-25$ & Multiple burial \\
\hline Clopton & S4.4 & Positive & $1361 / 62-1561$ & M & $60+$ & Individual burial, probably later than $\mathrm{S} 4.8$ \\
\hline Clopton & S4.4F & Unsampled & $1361 / 62-1561$ & Unknown & Foetus & Probably same grave as S4.4 \\
\hline Clopton & S4.7 & Unsampled & $1349-c .1500$ & Unknown & $13-17$ & Probable double burial with $\mathrm{S} 4.8$ \\
\hline Clopton & S4.8 & Tentative & $1349-c .1500$ & M & $18+$ & Probable double burial with S4.7, probably earlier than S4.4 \\
\hline Clopton & S6.3I & Positive & $1349-1561$ & M & $60+$ & $\begin{array}{l}\text { Probably individual burial or disarticulated remains that } \\
\text { represent a significant portion of an individual }\end{array}$ \\
\hline Clopton & S9.14 & Tentative & $1349-$ c. 1500 & M & $18-25$ & Individual burial, potentially same outbreak as $\mathrm{S} 9.24$ \\
\hline Clopton & S9.24 & Positive & $1349-$ c. 1500 & $\mathrm{~F}$ & $13-17$ & Individual burial, potentially same outbreak as S9.14 \\
\hline Augustinian Friary, cemetery & 1975 & Positive & $\begin{array}{l}\text { 1349-c. } 1380 \\
\text { prob. } 1349\end{array}$ & M & $26-35$ & Individual burial, laity \\
\hline Augustinian Friary, chapter house & 1458 & Positive & c. $1450-1538$ & M & $13-17$ & Individual burial, laity \\
\hline Augustinian Friary, chapter house & 1482 & Positive & $1476-1538$ & M & $7-12$ & Individual burial, novice \\
\hline Augustinian Friary, chapter house & 1771 & Positive & c. $1450-1538$ & M & $18-25$ & Individual burial, friar \\
\hline Midsummer Common & & Negative & $1550-1666$ & M & $18+$ & \\
\hline Midsummer Common & & Negative & $1550-1666$ & M & $18+$ & \\
\hline
\end{tabular}




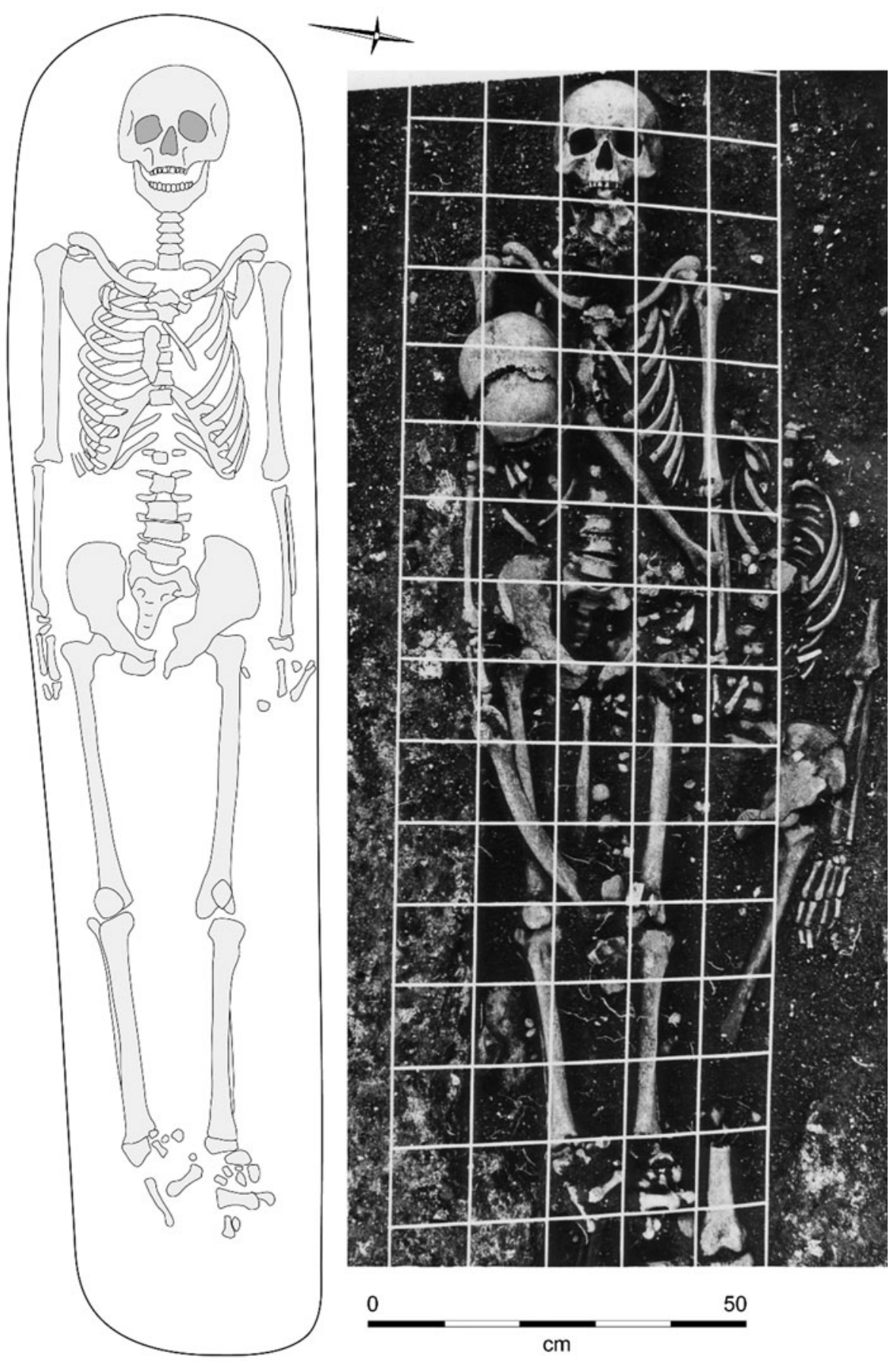

Figure 2. Plan and photograph of Y. pestis positive skeleton 82 from All Saints (plan by Vicki Herring for the 'Resurrecting Cambridge(shire)'s medieval dead' project, photograph courtesy of Vince Gregory). 


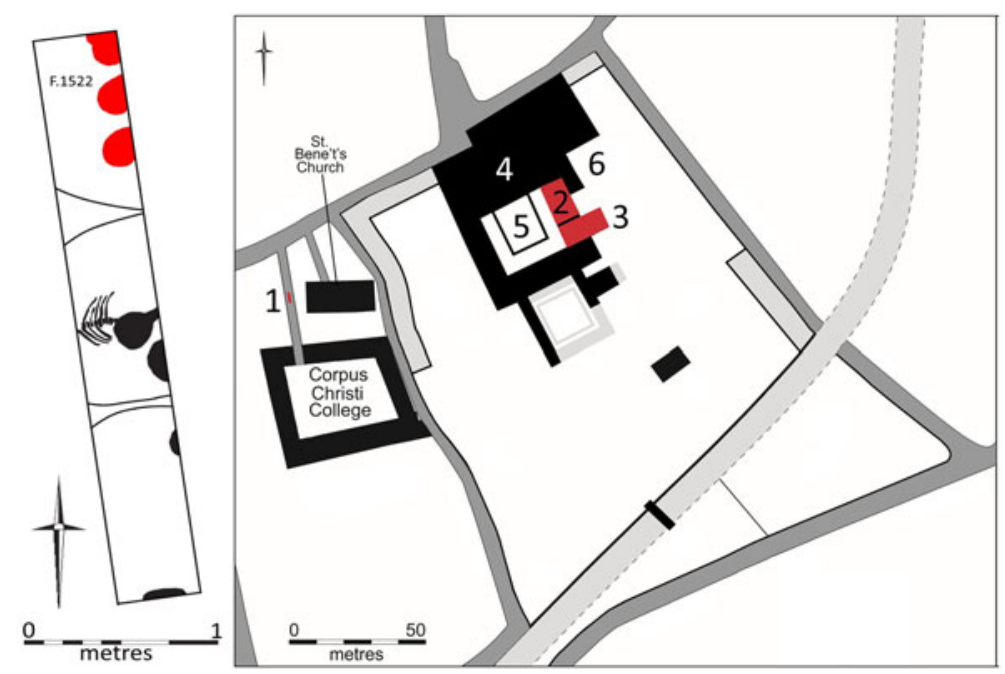

Figure 3. Plan of burial grounds at St Bene't's church and the Augustinian Friary, plus details of trench with mass burial at St Bene't's (red = sampled: 1) excavated trench at St Bene't's; 2) location of early friary cemetery; 3) friary chapter house; 4) friary church; 5) friary cloister; 6) friary later cemetery. (c) Cambridge Archaeological Unit.

outbreaks when additional burial space might presumably have been useful.

\section{St Bene't's}

St Bene't's (a contraction of Benedict's) parochial church in Cambridge was established in c. 1000-1050 and remains in use, with burial continuing until the 1850s. A strip of land along the western side of the churchyard was transferred to Corpus Christi College between 1352 and 1377, to form an entrance route between Bene't Street and the College. Part of this strip was excavated (Figure 3), revealing twenty-nine individual burials and part of one mass burial. The partially excavated mass burial (F.1522) took the form of a large feature with nearly vertical sides over $1.0 \mathrm{~m}$ by over $0.4 \mathrm{~m}$ in extent, but almost certainly significantly larger. It survived to a depth of $0.75 \mathrm{~m}$ but must originally have been at least $c .1 .8 \mathrm{~m}$ deep. At least five individuals were present; only the skull, some upper vertebrae and occasionally some clavicles were recoverable, as the rest of the skeletons extended outside the trench under live cables and pipes. The bodies were carefully laid out, on west-east alignments, apparently in extended supine positions, and stacked at least three deep. Four skeletons were tested, with two positive and one tentative identifications of $Y$. pestis (Table 2). It is probable that this mass burial relates to the Black Death as it is likely to predate the early/mid 1350s, but the possibility of it being linked to outbreaks in 1361-1362, 1369 and 1374 and later cannot be entirely excluded.

The St Bene't's mass burial is the only example known from Cambridge. Given the relatively low level of investigation in parish cemeteries locally and the high degree of truncation at most such sites by later burials, particularly eighteenth-nineteenth century brick-burial vaults, it is possible that parochial mass burials were common. Although only a relatively small investigation could take place, parts of just five skeletons were found and the extent of the original feature is uncertain. As 
bodies were stacked at least three deep, the feature is probably considerably larger than the investigated portion. Based on mass burials from East Smithfield (Grainger et al., 2008), if F.1522 was relatively small it might have contained two to three times the number of bodies identified. Alternatively, if it extended as far as St Bene't's Street it could have been large enough to contain up to $100-120$ bodies.

Corpus Christi College was founded by the two parish guilds of Corpus Christi and the Blessed Virgin Mary (Bateson, 1903; Hall, 1993; Hatcher, 2010; Barber, 2018). Such guilds were devotional and social organizations, one of whose main roles was to provide burial rites and commemorative masses for deceased members. The guild of the Blessed Virgin Mary was probably established in 1278-1285. Its bede roll is a document that lists the deceased who should be prayed for. At the end, there is a list of 'For the souls of the departed in the mortality and after the year of the Lord 1349 and after' (Bateson, 1903: 24-25). It lists eighty-nine individuals who died in 1349-1352. Although there is no way to be certain, assuming broadly normal mortality rates after the Black Death (see Smith, 2018 for a recent discussion and references), it is probable that some seventy to eighty of these individuals died of plague in 1349 .

There is no evidence that the guild of Corpus Christi existed before 1349. It was actively promoted during the spring and summer of that year but was not formally constituted until 1350 (Hall, 1993: 74). Construction of the Corpus Christi College buildings began in c. 1352 and completed by 1377 (Willis \& Clark, 1886 vol. I: 251). The last recorded intake of guild members was in 1358 and it probably effectively ceased to exist in the 1370s. There is no evidence that Corpus Christi ever developed as a conventional guild and it appears to have been founded solely to create a college, fulfilling both commemorative chantry obligations (endowing clerics to say masses for the souls of guild members) and a higher educational role, an idea that became fashionable after c. 1340 (Hall, 1993: 78). The College statutes of 1356 record that the master and two fellows were to be priests studying theology or canon law, praying the canonical hours (a unique requirement for an English college), serving as chaplain to the guild of Corpus Christi, and attending the funerals of all guild members. This effectively created a perpetual chantry, where the primary responsibility of the fellows and scholars was the provision of prayers for the welfare and prosperity of the guild members while alive and of their souls after death, in return for financial support. The Black Death would have resulted in numerous bequests to the guild. Many would have been deliberate, but additionally it is likely that many wills failed due to heirs having died. Executors could then gift estates for charitable purposes, with the original creator of the will potentially becoming a guild member posthumously (Barber, 2018: 60).

In the fourteenth century Cambridge colleges had unobtrusive entrances. As part of the construction of Corpus Christi College, the College gained a narrow strip along the western side of St Bene't's churchyard. This linked the College buildings to Bene't Street, forming the original main access route to the College leading to the 'old gateway' or 'ancient entrance' (Willis \& Clark, 1886 vol. IV: fig. 10). No legal documentation relating to this acquisition survives, but it probably took place in c. 1352 or soon after and certainly by 1377 . Before the nineteenth century, this was the only entrance to the College, apart from some staircases on Free School Lane, an unusual and unnecessary arrangement since an entrance from Free School Lane would have been perfectly practical and more normal. The fact the College 
was deliberately provided with an access route that lay over a mass burial from St Bene't's churchyard, whose location was presumably well known, is unlikely to be coincidental. The master and fellows of the College would have had to walk over it every time they entered or exited the college, including on their frequent trips to St Bene't's church to pray, as direct access from the College to St Bene't's was only added in the early sixteenth century. The location of the access route can be interpreted as an active strategy, incorporating the commemoration of plague victims into daily collegiate chantry practice and a particular reaction to the Black Death.

\section{St. Mary's, Clopton}

The cemetery of St Mary's parish church in the village of Clopton, nineteen kilometres south-west of Cambridge, was in use between the thirteenth century and 1561. Out of the seventeen skeletons sampled there, eleven to seventeen date to the second pandemic. Three tested positive for $Y$. pestis, plus two tentative instances. The stratigraphic sequence of the $Y$. pestis positive individuals indicates that victims of more than one outbreak are represented. Most of the positive/tentative results came from individual burials, interred in a manner indistinguishable from most of those excavated (Figure 4). One individual probably came from a double burial, although the excavation records are unclear.

There had been a church at Clopton since the late twelfth century, but it appears that a new church was constructed in a different location from its predecessor in the fourteenth century (Alexander, 1968: 58-59). This was probably the church that was dedicated at Clopton in 1352, an event that also occurred at several nearby parishes (Palmer, 1933: 34-35) but was generally uncommon in Cambridgeshire (Byng, 2017: 101-02, fig. 1.7). Ten candidates were also inducted into the clergy, indicating local community resilience and religious stability in the aftermath of the Black Death. Although the decline and ultimate abandonment of Clopton may partly be linked to the second pandemic, it owes more to a desire on the part of the leading local landowners to increase sheep farming (Palmer, 1933), although this may itself be related to the second pandemic.

\section{The Augustinian Friary}

The Augustinian Friary, founded in 1279/ 1280-1289, was one of the largest religious establishments in Cambridge, with up to seventy friars. It was both a working friary and a studium generale or centre of academic study, educating friars from England as well as continental Europe. The friary probably acquired the right to bury its members in 1290 and was granted the right to bury lay people in 1302. As lay people were usually granted burial in the friary in return for a substantial donation, burials of non-friars here probably represent moderately wealthy townspeople.

A cemetery of c. 1290-1380/1420 located south of the friary church probably contained a mixture of members of the Augustinian order and laity (Figure 5). A number of the burials had associated girdle buckles located on or near the pelvis, indicating that these individuals were buried in their clothing. The standardized nature of the clothed burials, with no evidence of other dress accessories and a dominance of particular buckle types (most frequently buckles with a D-shaped frame and rectangular plate, plus other types with a symmetrical double oval frame or oval or D-shaped frames and crescent or double 

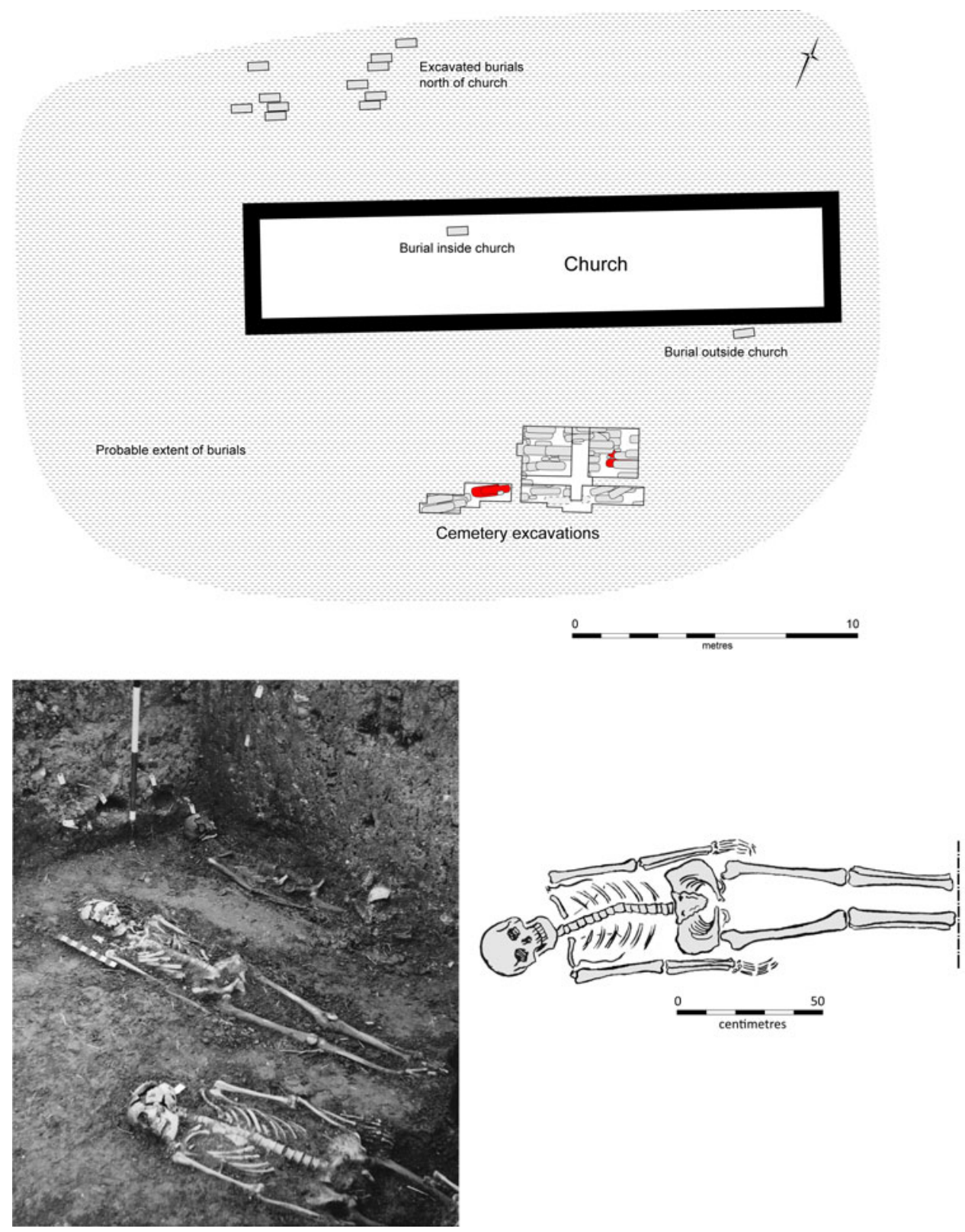

Figure 4. Plan of St Mary's Clopton church and cemetery with Y. pestis positive/tentative skeletons (red), plus photograph with Y. pestis positive skeleton S9.24 in centre and plan of Y. pestis tentative skeleton S9.14. Based on Alexander, 1968: 196, figs 1 and 2 and archive held by Cambridgeshire Records Office and the Duckworth Collection (plan by Vicki Herring for the 'Resurrecting Cambridge(shire)'s medieval dead' project).

crescent mounts) plus the fact that all the clothed individuals were of the appropriate sex and age to be members of the order suggests that only Augustinians were buried in their clothing (Cessford et al., forthcoming). Twenty-two skeletons were 


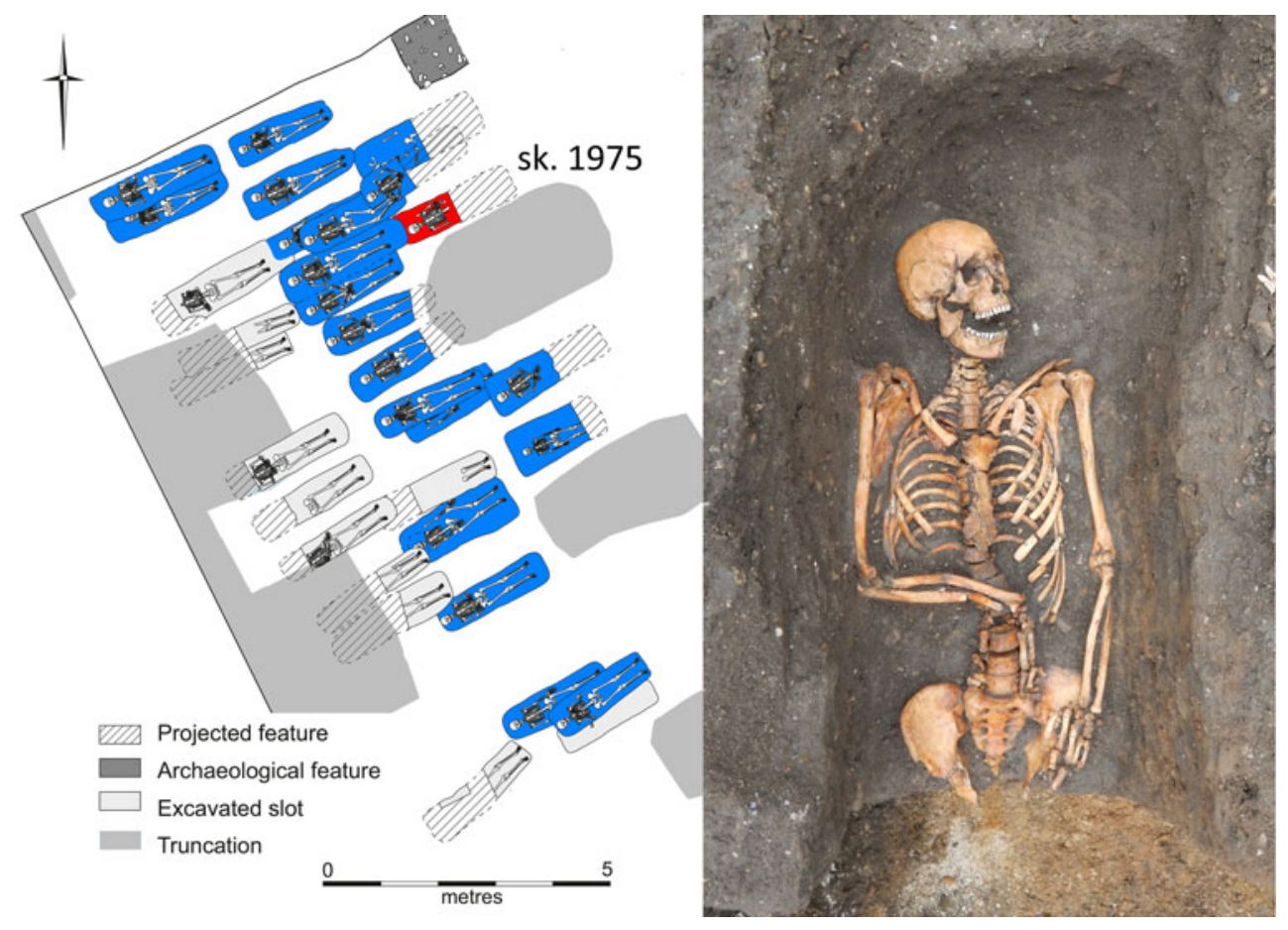

Figure 5. Plan of Cambridge Augustinian Friary cemetery, with Y. pestis positive burial (red) and other sampled burials that tested negative (blue), plus photograph of Y. pestis positive skeleton 1975. () Cambridge Archaeological Unit.

genetically tested, an estimated four to six individuals dating to the second pandemic. One individual who received a normal burial (sk.1975; Table 2) proved to be positive for $Y$. pestis, with the strain 'potentially identical to other Black Death genomes' (Spyrou et al., 2019: 3). There are also archaeological grounds for believing that this individual died before 1380 and that 1349 is the most likely date.

There were seventy friars in 1328; if the population was similar in 1349 , then a death rate of around forty to sixty per cent would have resulted in some twenty-eight to forty-two friars dying of plague. The dead may well have included the prior, John de Comberton, who is documented in 1343 and 1348 but had been succeeded by John Tuylet by 1350 . Although truncation removing entire graves and false negatives may have had some impact, finding only one positive result suggests that most burials of Black Death victims are located elsewhere in the friary. No more than forty to fifty individuals were buried in the cemetery in total; moreover, there are indications that it was in use over several decades and some of those buried were members of the laity. It is therefore likely that no more than a maximum of ten individuals in the cemetery could have been friars who died of plague and the actual total is likely to have been lower. This suggests that most friars who died during the Black Death were interred elsewhere.

No Augustinian friars were ordained in the diocese of Ely in 1347-1353, suggesting considerable disturbance caused by the Black Death. By 1356, the friars were repairing their church, indicating a relatively rapid recovery from the effects of the Black Death. Initially after the Black 
Death, the number of Augustinian friars in England appears to have been stable, probably because new entrants replaced the deceased, but this number fell around a generation later in a delayed reaction (Roth, 1966 vol. I: 84). Recruitment issues led to a lowering of the minimum age for accepting novices from fourteen to eleven years old and then ten, and dispensations such as priests being exempted from knowing Latin. There were also increased bequests of property to friaries and a rise in chantry chapels attached to friary churches (Roth, 1966 vol. I: 137, 141, 239).

A further six burials were excavated from a later chapter house, which was in use in c. 1380/1420-1538; this represents all or most of the individuals buried there (Figure 6). The chapter house was entered through a single doorway from the cloister, with benches providing seating around the walls of the room and an open central space. This building was second in importance only to the church. All brethren gathered here every morning for meetings, which included readings of the Martyrology (a list of martyrs and other saints arranged by their anniversaries or feasts) and Necrology (a list of the deaths of people related to the friary). All six burials were tested, with three proving positive for $Y$. pestis. The chapter house was altered at some point in the fifteenth century, in $c .1450$; all the $Y$. pestis positive burials were associated with this later phase (Table 2). One individual was radiocarbon-dated to after 1476 and the analysed $Y$. pestis aDNA from one skeleton also indicates a relatively late date (Spyrou et al., 2019: 5). Two of the Y. pestis positive burials had associated buckles (indicating, as mentioned, that they were members of the Augustinian order), while a third was probably a member of the laity. One individual with a buckle was no older than twelve and must therefore have been a novice recruited at what would have been an unacceptably young age before the changes caused by the second pandemic.

The most striking aspect of the way these plague victims were buried is the degree of investment in burial. Interment in the chapter house was a relatively complicated and laborious affair. The chapter house occupied a prominent, indoor and architecturally elaborate position in the friary's daily routine and burial within it was reserved for important individuals. It was more onerous than burial in an external cemetery and took place in a muchused space. The chapter house had a mortared tile floor; dozens of the tiles would have to be carefully lifted before a burial was inserted and either reinstated or replaced with a grave slab afterwards. In addition, there is evidence that the material excavated from the graves was removed from the chapter house, and a different material was used when the graves were backfilled. The burial of plague victims in the chapter house demonstrates a willingness to continue to expend considerable effort on individual burials during outbreaks. It also shows that there was no particular concern about plague being a 'bad death' or about contagion from those who died from plague. These burials can be conceptualized as the opposite of mass interments, which demonstrate the expenditure of minimum effort per individual buried.

A mixture of local and national textual sources suggests that, given the dates of c. 1450/1475-1538 for these burials, there may have been between some twelve and twenty plague outbreaks in Cambridge by the time(s) these individuals died. The later outbreaks were all less devastating than the initial Black Death, but still significant. Some probably claimed the lives of less than five per cent of the population and even the largest later outbreaks are 

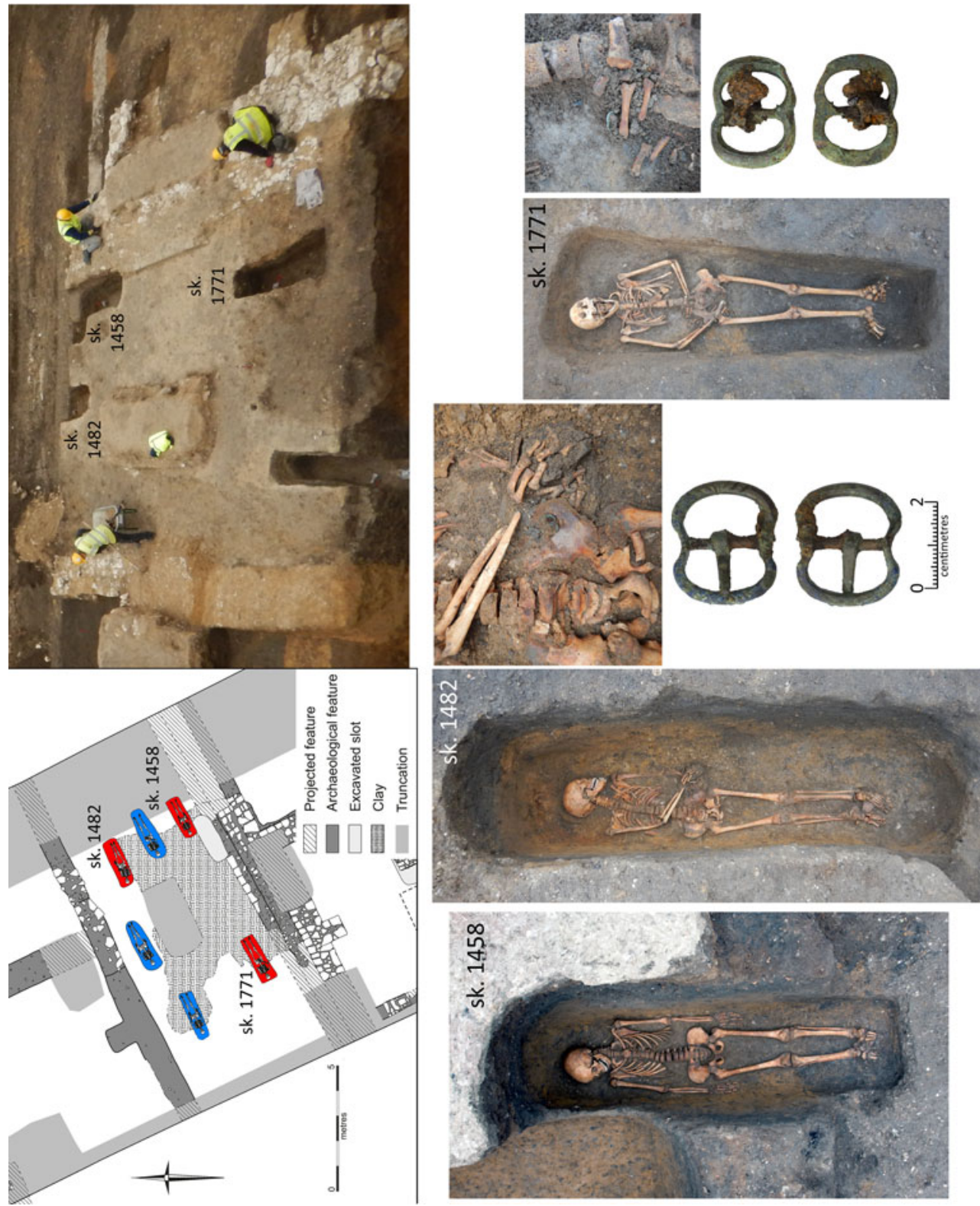

Figure 6. Plan of Cambridge Augustinian Friary chapter house, with Y. pestis positive burials (red) and other sampled burials (blue), plus photographs of chapter house during excavation, facing east, and Y. pestis positive skeletons. (C) Cambridge Archaeological Unit.

likely to have killed no more than between ten and twenty per cent of the population. The chapter house burials took place in a context where mass death through plague outbreaks was an occasional and traumatic, but not necessarily catastrophic, reality that society had at least partially adjusted to. Dozens if not hundreds of individuals at the Augustinian Friary must have died of plague while the chapter house was in 
use. Most of these must have been buried elsewhere, possibly in the friary church or cemetery. These contemporary burial grounds have not been located or investigated; but it is apparent that plague burials were conducted at multiple locations.

\section{The Hospital of St John}

The Hospital of St John the Evangelist was a small charitable institution providing care for the poor and infirm, established in c. 1190-1200 and dissolved in 1511 (Figure 7). The hospital was hit hard by the Black Death. While we know nothing of how the plague affected the inmates, records of clerical staff reveal that three successive masters of the hospital, Alexander Ixning, Robert Sprouston, and Roger Broom, died between May and June 1349. By the end, only two of the original six clerical brethren were still alive.

Ninety-seven skeletons from the hospital cemetery were tested for aDNA; forty-seven to fifty-seven of these are probably contemporary with the second pandemic. None proved positive for $Y$. pestis. While false negatives are possible, this is unlikely to be the entire explanation for this absence, particularly given the large number of skeletons sampled compared to the other sites. The burial environment and underlying geology are closely comparable to the Augustinian Friary, located only $400 \mathrm{~m}$ away, where $Y$. pestis was detected. The aDNA preservation was not abnormally low and allowed for the successful identification of commensal bacteria as well as human aDNA. It therefore appears improbable that a significant number of individuals who died of plague were buried here. This receives some support from the summed probabilities of the modelled radiocarbon determinations from the cemetery, which indicate a relatively low number of burials in the cemetery around the time of the Black Death.
Why should this be? The most likely scenario is that, as the Black Death hit Cambridge, the Hospital of St John may have stopped burying its dead in its general cemetery. The cemetery lies on the opposite side of the High Street from the main hospital site, where the chapel, infirmary, and other buildings were located. There is evidence, including textual references, disarticulated human bone (some with radiocarbon dates in the thirteenth century), and surviving monumental brasses, that burial took place in and around the chapel and cloister in the medieval period. When plague struck, the hospital staff and inmates may have barred their gates and remained within the hospital's walled precinct. As the staff died of plague, they would have been buried in or around the chapel. This would include the four masters and clerical brethren who died in 1349 and who would have anyway been buried within the chapel. To avoid venturing out of the hospital's gates, the practice of burying within the confines of the hospital may have been extended to the hospital's inmates, who would normally have been interred in the detached cemetery. This was presumably repeated during the many later plague outbreaks, as the cemetery continued in use until at least the mid-fifteenth century.

\section{Discussion}

As far as we are aware, our results are among the first identifications of $Y$. pestis linked to the second plague pandemic from individual burials in burial grounds that were not established because of the plague (for an example from Oslo, see Namouchi et al., 2018). This greatly expands our understanding of burial customs during the second pandemic, while the geographical focus allows us to compare a range of burial responses to 


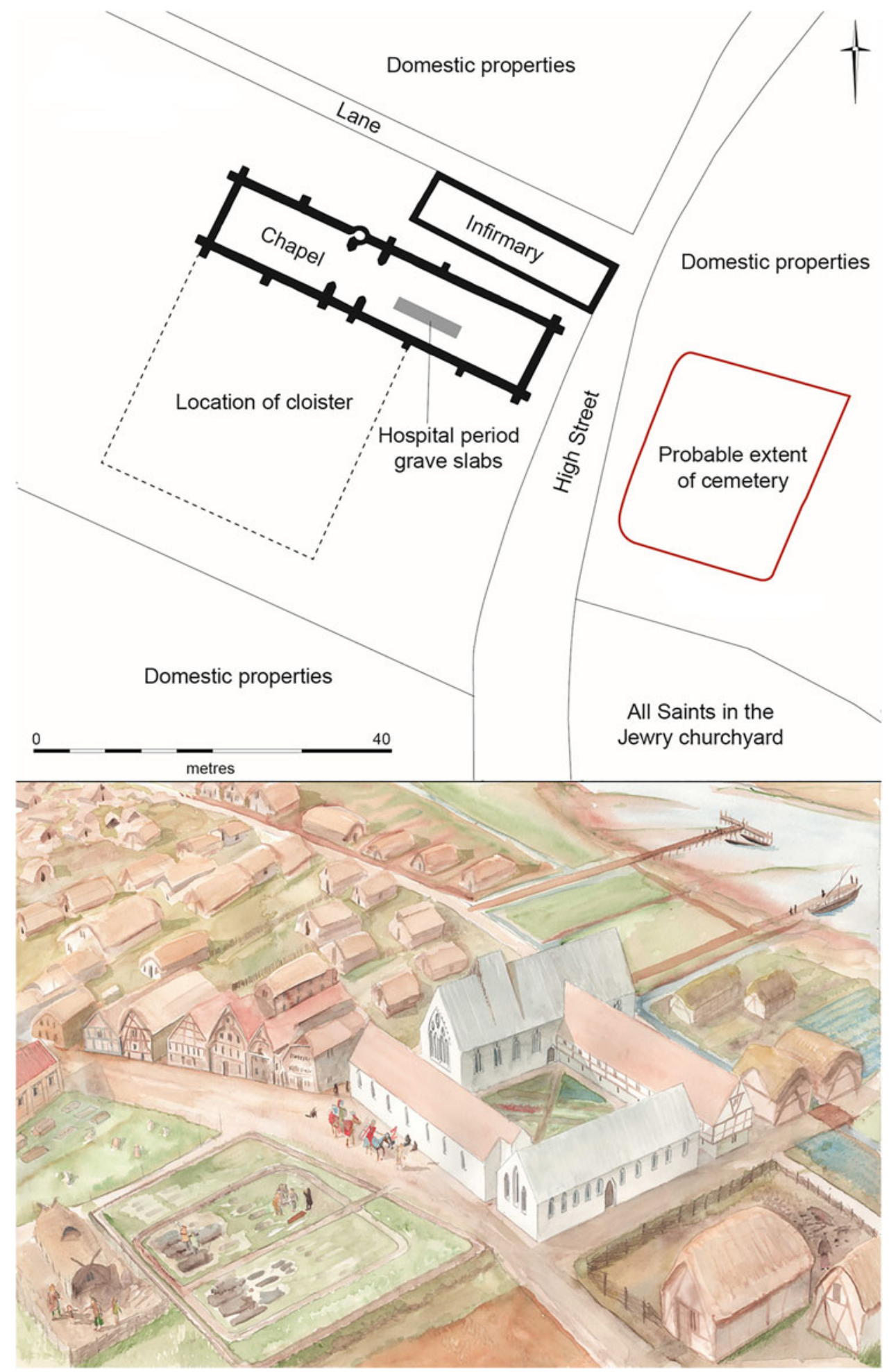

Figure 7. Plan of the Hospital of St John, showing location of detached cemetery (red), plus reconstruction of the Hospital in the fourteenth century facing southwest (plan by Vicki Herring and reconstruction by Mark Samuel, both for the 'After the Plague' project). 


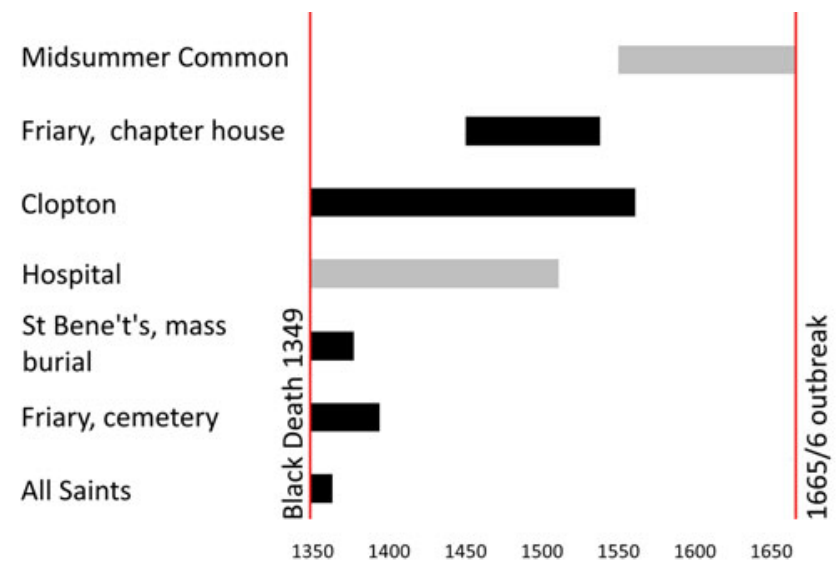

Figure 8. Timeline of sites with Y. pestis positive/tentative burials (black), plus sites where there were no positive results (grey).

that pandemic within a single town and its hinterland.

During the second pandemic, bodies of individuals who died of plague were interred in a variety of ways. Mass burials appear to be rather exceptional, whereas a significant proportion of burials were carried out in a highly normative way. While the archaeological discourse has previously focused on the exceptional, this article demonstrates that the normative can also be identified. The work of the 'After the Plague' project has revealed $Y$. pestis positive individuals from five burial grounds in or near Cambridge (Figure 8), nearly doubling the number of locations from the British Isles. Perhaps some 2300-3500 people died of plague in a few months in 1349 in Cambridge and were buried at seventeen parish churches, a nunnery, two priories, and four friaries, as both individual interments and mass burials. By the time of the last outbreak in $1665 / 1666$, many tens of thousands of inhabitants of Cambridge had died of plague. $Y$. pestis aDNA has been identified in eight Cambridge inhabitants, of whom six are likely to have died in 1349 . While at one level this is a negligible number, it represents a revolution in our understanding.
Archaeologists have long recognized that many plague victims were buried individually in pre-existing cemeteries and churches, in a manner typical of the period. Such burials would 'probably be archaeologically indistinguishable from other ... interments' (Hawkins, 1990: 641; see also Grainger et al., 2008: 29). Without biomolecular evidence, it had previously been impossible to move beyond a general recognition of this phenomenon. The focus on emergency cemeteries and mass burials has created a biased impression in the literature, now tempered by the recognition of individual normative burials in 'ordinary' cemeteries at All Saints, the cemetery and chapter house of the Augustinian Friary, and at Clopton. While it would be tempting to create a dichotomy between individual and mass burials, this should not be overstated. Individuals in mass burials, at least those dating to the fourteenth-fifteenth centuries, were generally laid out in a careful and respectful manner in an extended supine position with their heads to the west replicating the practice of individual burials as far as possible.

Beyond this, while research into 'normal' plague burials is still incipient, it is striking 
how even our limited results provide suggestive vignettes of very different responses to the plague. Within one townscape, it is possible to find:

- Individuals buried within a normal parish church cemetery with rites indistinguishable from any others (All Saints), even within a parish severely affected by plague. The same is true in rural parish cemeteries (Clopton).

- A mass burial of at least five individuals within a parish cemetery (St Bene't's). This signals a community overwhelmed and unable to cope through normal burial process, but still treating bodies with as much respect as possible. Presumably, this was traumatic enough that the location was incorporated into a place of memory for a subsequent religious establishment, Corpus Christi College, founded explicitly in response to the Black Death.

- Within a large, high-status religious institution (the Augustinian Friary), clerics who had died of plague were buried in the normal manner. Both clerics and members of the laity killed in later fifteenth-sixteenth-century waves of plague were sometimes interred in the architectural heart of the community. This shows a concern to mark their status, requiring considerably more than the minimum effort, plague victim or not. Other individuals who died of plague were interred elsewhere at the friary, as befitted their status.

The systematic testing of ninety-seven individuals buried at the Hospital of St John, including at least forty-seven who lived during the second pandemic, yielded no positive $Y$. pestis identifications, while plague appeared in much smaller numbers of samples from contemporary contexts elsewhere and textual sources record individuals dying during the Black Death. This could be suggestive of an institution barring its gates against the plague, no longer venturing out to bury its dead in its detached cemetery, and instead burying them somewhere within its enclosed grounds. However, further in-depth studies are necessary to investigate differences in aDNA preservation.

\section{Conclusion}

Archaeological studies of second pandemic burials need no longer focus almost exclusively on emergency cemeteries established in response to the plague or on mass burials. Normative single burials in preexisting burial grounds were shown to be suitable sources for $Y$. pestis aDNA, including those from earlier excavations as samples from skeletons excavated in the 1960s and 1970s proved viable. These offer valuable insights into the coping strategies of different communities dealing with epidemic events on a societal level, drawing a more comprehensive picture of frailty and resilience in past societies. This broadening demonstrates the potential for a revolution in the archaeological understanding of societies facing severe epidemic outbreaks. If emergency cemeteries and mass burials are atypical, with most plague victims instead receiving individual burial in normal cemeteries, this calls into question how representative these exceptional sites are. While the numbers of plague victims in individual burials identified so far is too small to draw any demographic conclusions about the sex and age of those who died, it at least suggests that emergency cemeteries and mass burials are but one side of the story.

\section{SupPlementary Material}

To view supplementary material for this article, please visit https://doi.org/10.1017/ eaa.2021.19. 


\section{ACKNowledgements}

The 'After the Plague' project is supported by the Wellcome Trust (Collaborative Grant 200368/Z/15/Z). Some graphics and radiocarbon determinations were funded by the McDonald Institute for Archaeological Research, as part of the 'Resurrecting Cambridge(shire)'s medieval dead' project and work has also been supported by St John's College, Cambridge. A version of this article was presented at the Society for Medieval Archaeology conference 'The Long Black Death: New Perspectives' (York, July 2019). We are grateful to all our colleagues on the 'After the Plague' project, and to the Cambridge Archaeological Unit, Cambridgeshire County Council Historical Environment Team, and the Duckworth Laboratory for access to their collections and sampling permissions. Thanks are also due to the original excavators of All Saints, Paul Craddock and Vince Gregory. We are grateful to the four anonymous reviewers for their comments. The aDNA lab at the University of Tartu is supported by the European Union, through the European Regional Development Fund [Project No. 2014-2020.4.01.160030] (Christiana Scheib, Meriam Guellil, Marcel Keller), and the Estonian Research Council, personal research grant [PRG243] (Christiana Scheib).

\section{REFERENCES}

Alexander, J.A. 1968. Clopton: The Life-Cycle of a Cambridgeshire Village. In: L.M. Munby, ed. East Anglian Studies. Cambridge: Heffer \& Sons, pp. 48-70.

Barber, R. 2018. The City of London and the Founding of the Guild of Corpus Christi. In: J.S. Lee \& C. Steer, eds. Commemoration in Medieval Cambridge. Martlesham: Boydell \& Brewer, pp. 52-60. https://doi. org/10.1017/9781787443471.004
Bateson, M. 1903. Cambridge Gild Records (Cambridge Antiquarian Society Octavo Publication 39). Cambridge: Cambridge Antiquarian Society.

Benedictow, O. 2004. The Black Death, 13461353: The Complete History. Woodbridge: Boydell.

Byng, G. 2017. Church Building and Society in the Later Middle Ages. Cambridge: Cambridge University Press. https://doi. org/10.1017/9781316661765

Casson, C., Casson, M., Lee, J.S. \& Phillips, K. 2020. Compassionate Capitalism: Business and Community in Medieval England. Bristol: Bristol University Press. https:// doi.org/10.2307/j.ctvzsmcq4

Cessford, C., Hall, A., Mulder, B., Neil, B., Riddler, I. \& Wiles, J. forthcoming. Buried with their Buckles On: Clothed Burial at the Augustinian Friary, Cambridge. Medieval Archaeology.

Dennis, D.T., Gage, K.L., Gratz, N.G., Poland, J.D. \& Tikhomirov, E. 1999. Plague Manual: Epidemiology, Distribution, Surveillance and Control. Geneva: World Health Organization. https://apps.who.int/ iris/handle/10665/66010

Evans, D.H. 2002. Buried with the Friars. In: P. Bahn, ed. Written in Bones: How Human Remains Unlock the Secrets of the Dead. Newton Abbot: David \& Charles, pp. 27-31.

Grainger, I. \& Phillpotts, C. 2011. The Cistercian Abbey of St Mary Graces, East Smithfield, London (MOLA Monograph 44). London: Museum of London Archaeology.

Grainger, I., Hawkins, D., Cowal, L. \& Mikulski, R. 2008. The Black Death Cemetery, East Smithfield. London: Museum of London Archaeology Service.

Green, M.H. ed. 2015. Pandemic Disease in the Medieval World: Rethinking the Black Death. Kalamazoo: Arc-Medieval Press. https://doi.org/10.2307/j.ctvmd83jc

Hall, C.P. 1993. The Gild of Corpus Christi and the Foundation of Corpus Christi College: An Investigation of the Documents. In: P.N.R. Zutschi, ed. Medieval Cambridge: Essays on the PreReformation University. Woodbridge: Boydell, pp. 65-91.

Hartle, R. 2017. The New Churchyard: From Moorfields Marsh to Betblem Burial Ground, Brokers Row and Liverpool Street (MOLA/ 
Crossrail Archaeology 10). London: Museum of London Archaeology.

Hatcher, J. 2010. For the Souls of the Departed in the Mortality of the Year of the Lord 1349 and After. The Letter, 89: 14-23.

Hawkins, D. 1990. The Black Death and the New London Cemeteries of 1348. Antiquity, 64: 637-42.

HMC 1877. Sixth Report of the Royal Commission on Historical Manuscripts. Part I: Report and Appendix. London: HMSO.

Hübler, R., Key, F.M., Warinner, C., Bos, K. I., Krause, J. \& Herbig, A. 2019. HOPS: Automated Detection and Authentication of Pathogen DNA in Archaeological Remains. Genome Biology, 20, 280. https:// genomebiology.biomedcentral.com/articles/ 10.1186/s13059-019-1903-0

Keller, M., Spyrou, M.A., Scheib, C.L., Neumann, G.U., Kröpelin, A., HaasGebhard, B., et al. 2019. Ancient Yersinia pestis Genomes from across Western Europe Reveal Early Diversification During the First Pandemic (541-750). Proceedings of the National Academy of Sciences, 116: 12363-72. https://doi.org/10.1073/pnas. 1820447116

Namouchi, A., Guellil, M., Kersten, O., Hänsch, S., Ottoni, C., Schmid, B.V., et al. 2018. Integrative Approach Using Yersinia pestis Genomes to Revisit the Historical Landscape of Plague During the Medieval Period. Proceedings of the National Academy of Sciences, 115: E11790-E11797. https:// doi.org/10.1073/pnas.1812865115

Palmer, W. 1933. A History of Clopton, Cambridgeshire. Proceedings of the Cambridge Antiquarian Society, 33: 3-60. https://doi. org/10.5284/1034398

Pfizenmaier, S. 2016. Charterhouse Square: Black Death Cemetery and Carthusian Monastery, Meat Market and Suburb (MOLA/Crossrail Archaeology 7). London: Museum of London Archaeology.

Rasmussen, S., Allentoft, M.E., Nielsen, K., Orlando, L., Sikora, M., Sjögren, K-G., et al. 2015. Early Divergent Strains of Yersinia pestis in Eurasia 5,000 Years Ago. Cell, 163: 571-82. https://doi.org/10.1016/ j.cell.2015.10.009

Roth, F. 1966. The English Austin Friars 12491538. New York: Augustinian Historical Institute.

Sexton, D.J. \& Stout, J. 2018. Clinical Manifestations, Diagnosis, and Treatment of
Plague (Yersinia pestis Infection) [online] [accessed April 2020]. Available at: $<$ https://www.uptodate.com/contents/clinicalmanifestations-diagnosis-and-treatment-ofplague-yersinia-pestis-infection>

Smith, R. 2018. Some Emerging Issues in the Demography of Medieval England and Prospects for their Future Investigation. Local Population Studies, 100: 13-24. https://doi.org/10.35488/lps100.2018.13

Spyrou M.A., Keller, M., Tukhbatova R.I., Scheib C.L., Nelson E.A., Andrades Valtueña, A., et al. 2019. Phylogeography of the Second Plague Pandemic Revealed through Analysis of Historical Yersinia pestis Genomes. Nature Communications, 10: article 4470. https://doi.org/10.1038/ s41467-019-12154-0

Stoakley, M. 2019. 'Great fears of the sickness here in the City ... God preserve us all ...'. A Plague Burial Ground in Leith, 1645: An Archaeological Excavation at $\mathrm{St}$ Mary's (Leith) RC Primary School, Leith Links, Edinburgh. Scottish Archaeological Internet Reports, 86: 1-82. https://doi.org/ 10.9750/issn.2056-7421.2019.86

Stone, R. \& Appleton-Fox, N. 1996. A View from Hereford's Past: A Report on the Archaeological Excavation in Hereford Cathedral Close in 1993. Little Logaston: Logaston Press.

Willis, R. \& Clark, J.W. 1886. The Architectural History of the University of Cambridge. Cambridge: Cambridge University Press.

Willmott, H., Townend, P., Mahoney Swales, D., Poinar, H., Eaton, K. \& Klunk, J. 2020. A Black Death Mass Grave at Thornton Abbey, Lincolnshire: The Discovery and Examination of a Fourteenth-Century Rural Catastrophe. Antiquity, 94: 179-96. https:// doi.org/10.15184/aqy.2019.213

Wood, D.E., Lu, J. \& Langmead, B. 2019. Improved Metagenomic Analysis with Kraken 2. Genome Biology, 20, 257. https:// genomebiology.biomedcentral.com/articles/ 10.1186/s13059-019-1891-0

\section{Biographical Notes}

Craig Cessford has worked in commercial and academic archaeology for thirty years, with a particular interest in medieval and later urban archaeology. He is currently senior project officer at the Cambridge 
Archaeological Unit and co-investigator on the 'After the Plague' project, Department of Archaeology, University of Cambridge.

Address: McDonald Institute for Archaeological Research and Cambridge Archaeological Unit, University of Cambridge, Downing Street, Cambridge CB2 3ER, UK. [email: cc250@ https://orcid.org/0000-0001-7291-7828

Christiana L. Scheib is a palaeogeneticist and is currently the head of the Ancient DNA research group at the Institute of Genomics, University of Tartu, Estonia. She is a research fellow at St John's College, Cambridge, an honorary research associate of the McDonald Institute for Archaeological Research in Cambridge, and was a post-doctoral researcher on the 'After the Plague' project. Her $\mathrm{PhD}$, Genetic History of Southern California and its Channel Islands: A Population-scale Study of Ancient Whole Genome Data, was awarded by the University of Cambridge in 2016.

Address: Institute of Genomics, University of Tartu, Riia 23B, Tartu, Estonia 51010. [email: cls83@ut.ee]. ORCiD: https:// orcid.org/0000-0003-4158-8296

Meriam Guellil is a palaeogeneticist specializing in ancient pathogen genomics and metagenomics and is currently a postdoctoral research fellow at the Institute of Genomics, University of Tartu, Estonia. Her PhD, Disease During the Second Plague: Genomic, Metagenomic and Phylogenetic Analysis of Ancient DNA from Putative Plague Victims, was awarded by the University of Oslo in 2018.

Address: Institute of Genomics, University of Tartu, Riia 23B, Tartu, Estonia
51010. [email: meriam.guellil.ac@gmail. com]. ORCiD: https://orcid.org/00000002-7235-4604

Marcel Keller is a palaeogeneticist specializing in ancient pathogen genomics and is currently postdoctoral research fellow assistant for ancient DNA at the Institute of Genomics, University of Tartu, Estonia. He wrote his dissertation, Yersinia Pestis Genomes of the First and Second Plague Pandemic Recovered from Ancient DNA, at the Max Planck Institute for the Science of Human History in Jena and was awarded his Dr. rer. nat. by the Friedrich Schiller University Jena in 2020.

Address: Institute of Genomics, University of Tartu, Riia 23B, Tartu, Estonia 51010. [email: marcel.keller@ut.ee]. ORCiD: https://orcid.org/0000-0001-9668-6817

Craig Alexander is an independent researcher and specialist in the modelling of radiocarbon determinations.

Address: [email: craiga304@gmail.com]. ORCiD: https://orcid.org/0000-0001-75396415

Sarah A. Inskip is an osteoarchaeologist at the University of Leicester. Her research focuses on revealing the impact of the arrival and commodification of tobacco on the health of Western Europeans from 1600 to 1900. She was previously a post-doctoral researcher on the 'After the Plague' project at the University of Cambridge and prior to that assistant professor at Leiden University. Her PhD, Islam in Iberia or Iberian Islam: Sociobioarchaeology and the 
Analysis of Emerging Islamic Identity in Early Medieval Iberia, was awarded by the University of Southampton in 2014. She has just received a UK Research and Innovation (UKRI) Future Leaders Fellowship at the University of Leicester to explore the impact of tobacco on health in post-medieval Western Europe.

Address: School of Archaeology and Ancient History, University of Leicester, LE1 7RH, UK. [email: si159@le.ac.uk]. ORCiD: https://orcid.org/0000-0001-74242094
John Robb is a professor at the Department of Archaeology, University of Cambridge. His research interests include archaeological and anthropological theory, European prehistory, and European prehistoric and human skeletal analysis. $\mathrm{He}$ is the principal investigator on the 'After the Plague' project.

Address: Department of Archaeology, University of Cambridge, Downing Street, Cambridge CB2 3ER, UK. [email: jer39@ cam.ac.uk]. ORCiD: https://orcid.org/ 0000-0002-7987-4549

\section{Au-delà des fosses communes : analyses génétiques permettant d'identifier les réactions à l'égard de la Peste Noire dans le Cambridgeshire au Moyen Âge}

L'ADN ancien de Yersinia pestis a été identifié parmi les squelettes provenant de quatre cimetières urbains à Cambridge en Angleterre et dans un cimetière de la campagne environnante. Ces sépultures datant d'entre 1349 et 1561 apr. J.-C. contenaient des individus morts de la peste lors de la seconde pandémie de peste en Europe au Moyen Âge. La plupart avaient été enterrés dans des tombes individuelles ordinaires et non dans des fosses communes. Ce résultat marque une avancée majeure en archéologie en mettant l'accent sur les pratiques funéraires courantes au Moyen Âge plutôt que sur quelques découvertes exceptionnelles de fosses communes. Une considération détaillée des contextes des sépultures permet aux auteurs d'identifier les diverses réactions envers la seconde pandémie de peste à Cambridge et aux alentours et de formuler un récit plus fourni qu'auparavant. Translation By Madeleine Hummler

Mots-clés: peste, seconde pandémie de peste, ADN ancien, sépultures, Cambridge

\section{Jenseits der Massengräber: genetische Untersuchungen zur Identifizierung der Reaktionen auf die Pest im Cambridgeshire}

Vier Friedhöfe in der Stadt Cambridge in England und ein ländlicher Kirchhof in der Umgebung lieferten Nachweise auf Yersinia pestis mittels alter DNA. Die Skelette, die zwischen 1349 und 1561 datieren, gehören zu Individuen, die der zweiten Pest pandemie zum Opfer fielen. Die meisten stammen aus regelhaften Einzelgräbern und nicht aus Massengräbern. Dieses Ergebnis stellt einen wesentlichen Fortschritt für die archäologische Forschung dar, da es den Fokus weg von einigen wenigen außergewö̈hnlichen Massengräbern verschiebt und den Schwerpunkt auf normale mittelalterliche Grabsitten legt. Die detaillierte Untersuchung des Kontexts der Bestattungen erlaubt es, eine Serie von Reaktionen auf die zweite Pest Pandemie innerhalb einer Stadt und ibrer Umgebung zu identifizieren und ein differenzierteres Bild als zuvor zu schildern. Translation By Madeleine Hummler

Stichworte: Schwarze Pest, zweite Pest Pandemie, aDNA, Gräber, Cambridge 